\title{
Determination the site of antibiotic resistance genes in Escherichia coli isolated From Urinary Tract Infection
}

\author{
Karzan Abdulmuhsin Mohammad \\ Medical Analysis Department \\ Science Faculty | Ishik university \\ College of Education | Salahaddin University \\ Erbil, Iraq \\ karzan.mohammad@ishik.edu.iq
}

\author{
Zirak F. Ahmed \\ Biology Department \\ College of Education \\ Salahaddin University \\ Erbil, Iraq \\ zirak.ahmad@su.edu.krd
}

\author{
Bayar H. Mohammed \\ Biology Department \\ College of Education \\ Salahaddin University \\ Erbil, Iraq \\ bayar.mohammed@su.edu.krd
}

\author{
Rasti H. Saeed \\ Biology Department \\ College of Education \\ Salahaddin University \\ Erbil, Iraq \\ rastee.saeed@su.edu.krd
}

\begin{abstract}
This study includes isolation of 25 isolates of Escherichia coli (E. coli ) strain from urinary tract samples in a pregnant woman. Microbiological and biochemical tests were used to identify the resistant bacteria of this genus. Screening methods were used to determine bacterial isolates for their resistance to 10 antibiotics include: Amikacin (Ak), Amoxicillin (Ax), Ampicillin (Ap), Chloramphenicol (Cm), Ciprofloxacin (Cip), Erythromycin (Er), Nalidixic acid (Nal), Penicillin (Pen), Tetracycline (Tet) and Trimethoprim (Tm). The isolates E4, E9, E16, and E17 were resistant to all antibiotics used in the current study using the disk diffusion method. In contrast, the resistance percentage for all antibiotics ranged between 28-96\%. Sites of resistance genes and hemolysin production genes were characterized by tranformation techniques in the E4 and E16. The results showed that the antibiotic resistance genes of Amikacin, Erythromycin, Tetracyclin, and Trimethoprim were located on a plasmid, whereas Amoxicillin, Ampicillin, Chloramphenicol, Ciprofloxacin, Nalidixic acid and Penicillin were located on chromosomal DNA. The results also demonstrated an inability to produce alpha or beta-hemolysin indicating that the genes which are responsible for hemolysin production were also located on chromosomal DNA.
\end{abstract}

Keywords: E. coli , antibiotics, resistant genes, plasmid

\section{INTRODUCTION}

Urinary tract infections (UTIs) are defined as the presence of bacteria in urine along with symptoms of infection. The infection is important clinically because of many organelles of the urinary tract may involve such as urethra, bladder, uterus, and kidney. All age groups are susceptible to this type of infection, but the frequency in women is higher than men [1] add reference??. The reason may be attributed to many factors including short urethra, the absence of prostates secretion, pregnancy and easy contamination of the urinary tract with fecal flora. Additionally, during pregnancy, the physiological increase in plasma volume decreases the concentration of urine up to $70 \%$. As a result, pregnant women develop glucosuria, which encourages bacterial growth in the urine [2].

Antibiotic resistance microorganisms are a health threat in the world which encourages the medicine manufactures to produce new generations of yearly antibiotics to solve this problem, especially there are some bacteria considered a multiple antibiotic resistance such as Escherichia coli, Klebsiella spp., Staphylococcus spp., Pseudomonas spp., Proteus spp. and others [3].

One of the major problems that associated with the risk of $E$. coli is their ability to resist a wide variety of antibiotics that introduced as therapeutic agents. These mainly due to the presence of extrachromosomal elements that harbor a resistant gene or R-factor which can be passed among bacteria of the same species or to other strains of $E$. coli through different mechanisms include transformation, conjugation and transduction processes. Therefore, controlling and elimination of the resistance that conferred by R-plasmid by using biological mutagens, physical and chemical or other curing agents will be quite useful to put out such resistance eliments [4].

Finally, the epidemiology of drug resistant E. coli and other gram-negative enteric bacteria is undergoing a remarkable change in the feature with the widespread occurrence or resistance transfer factors (RTF), which may have transferred to drug-sensitive strain by conjugation and transduction [5]. So the present work comprises: Isolation and identification of $E$. coli that cause urinary tract infection in pregnant women, study the resistance of $E$. coli toward different antibiotics understudy, isolation and purification of plasmid DNA content from E. coli, and determination the site of antibiotic resistance genes by genetic transformation. 


\section{METHODS AND MATERIALS}

\subsection{Specimens collection}

Urine sample: Mid-stream of 75 urine samples were collected in sterile cups from pregnant women suffering from urinary tract infections attending Health Center (Nazdar Bamerni), during the period 15th July 2017 to 7th September 2017.

\subsection{Processing of Samples:}

\subsubsection{General urine examination:}

For microscopic examination, $5 \mathrm{ml}$ of urine was centrifuged, the supernatant was discarded, the deposit then re-suspended, and $0.1 \mathrm{ml}$ applied on a clean microscopic slide. The precipitated material was examined for the presence of leukocytes (pus cells), erythrocytes (RBC), mucus, bacteria, and parasites, along with crysals and casts[6].

\subsubsection{Urine culture (isolation of $E$. coli )}

A loop full of undiluted urine samples was spread on culture media (blood and MacConkey agar) plates. The plates were incubated at overnight at $37^{\circ} \mathrm{C}$. Well isolated single colonies were sub-cultured on the same media to check for the purity of the isolated bacteria. Purified isolates were identified using microscopic, morphological, biochemical and API 20E system as a more accurate method for identification

\subsection{Hemolysis on blood agar}

On blood agar, E. coli and most of the other enteric bacteria form circular, convex, and smooth colonies with B-hemolysis produced by some strains of E. coli [4].

\subsection{Antimicrobial susceptibility test}

This test was performed according to write the name of the author with no year then [6]. Antibiotic-impregnated discs with required concentration were dispensed on the surface of Mueller-Hinton agar medium that has been spread with a pure bacterial suspension of $105 \mathrm{CFU} / \mathrm{ml}$. After incubation, inhibition zones were measured and translated into predetermined categories as susceptible, intermediate, or resistant (Table-3).

\subsection{Isolation of plasmid DNA content from bacterial isolates understudy}

In order to isolate the plasmid DNA, a method described by [7] was employed with some modification and includes the following steps: $50 \mathrm{ml}$ of sterilized nutrient broth media containing appropriate antibiotic was inoculated with single colony of tested bacterial isolate, and incubated in a shaking incubator $(100 \mathrm{rpm})$ at $37^{\circ} \mathrm{C}$ overnight. Then, centrifugation was carried out for 10 minutes at $8000 \mathrm{rpm}$. The pellet re-suspended in $2 \mathrm{ml}$ solution I (Glucose 20\%, EDTA $20 \mathrm{Mm}$ and Sodium Dodecyl Sulfate $10 \%$ ), then $100 \mu \mathrm{l}$ of $50 \mu \mathrm{g} / \mathrm{ml}$ lysozyme (BHD, England) was added to the suspension, left at room temperature for 10 minutes, after that $4 \mathrm{ml}$ of solution II added, vortexed and left on ice for 10 minutes. Then $2 \mathrm{ml}$ of cold $5 \mathrm{M}$ potassium acetate was added and left on ice for 10 minutes, after that centrifugation at $8000 \mathrm{rpm}$ to precipitate cell debris and high molecular weight DNA were performed. In order to remove protein, the supernatant transferred to clean tube and an equal volume of chloroform: Isoamyl alcohol (24:1) was added, centrifuged for 10 minutes at $8000 \mathrm{rpm}$, this step repeated several times. The aqueous layer was transferred to clean tube and its volume estimated, then $1 / 10$ of this volume solution III added with two volume of absolute ethanol to precipitate the nucleic acids, the mixture was left for 30 minutes at $-20^{\circ} \mathrm{C}$, then centrifuged for 10 minutes at 8000 rpm. The pellet washed with $5 \mathrm{ml}$ of $70 \%$ ethanol, centrifuged for 10 minutes at $8000 \mathrm{rpm}$, after that the pellet dried, re-suspended with $0.5 \mathrm{ml}$ Tris-EDTA buffer and stored at $-20^{\circ} \mathrm{C}$.

\subsection{Spectrophotometric quantification of plasmid DNA}

A method utilized by Sambrook and Russel [ 8] was followed: A 100 microliter of prepared plasmid DNA was diluted by TE buffer to $1 \mathrm{ml}$ and the optical density (O.D.)was measured at $260 \mathrm{~nm}$. The concentration of plasmid DNA calculated according to the equation:

Optical density of DNA $\mathrm{X}$ dilution factor $\mathrm{X}$ $50 \mu \mathrm{g} / \mathrm{ml}=\mathrm{No} . \mu \mathrm{g} / \mathrm{ml}$

\subsection{Site determination of the genes resistance to the antibiotic}

The procedure carried out by isolation and purification of DNA plasmid from the bacterial isolates. The DNA was transformed into standard strains of E. coli which used as bacterial hosts for DNA uptake. The transformation process of the isolated DNA plasmids was performed as follow:

\subsubsection{Preparation of the competent cells}

Competent cells were prepared using $5 \mathrm{ml}$ of Lactose broth which was inoculated with a single colony of $E$. coli $D H 5 \alpha$ free of plasmids. The samples were incubated in a shaker incubator $(100 \mathrm{rpm})$ for 24 hours at $37^{\circ} \mathrm{C}$ and then one $\mathrm{ml}$ of bacterial culture was added to $50 \mathrm{ml}$ of LB broth and the samples were incubated with shaking at $37^{\circ} \mathrm{C}$ for 3-4 hrs. The optical density of the bacterial cultures growth (OD650) was taken using a spectrophotometer to measure the logarithmic-phase of $E$. coli which typically ha an (OD650 of $0.5-0.7)$. The cells were harvested by centrifugation at 5,000 rpm for $10 \mathrm{~min}$ and the supernatant was discarded, then the pellet was resuspended one $\mathrm{ml}$ of ice-cold $0.1 \mathrm{M} \mathrm{CaCl} 2$. The same solutions and concentrations were used for all the samples. The resuspended cells samples were left on ice for $30 \mathrm{~min}$ followed by centrifugation for 10 minutes with the same above conditions. Finally, the supernatant discarded, and the pellet of bacterial cells was resuspended in $2.5 \mathrm{ml}$ of ice-cold $\mathrm{CaCl} 2$ [8].

\subsubsection{DNA uptake}

Transformation of DNA plasmid to competent cells of $E$. coli DH5 $\alpha$ :

Extracted DNA plasmids from isolate strains of $E$. coli were plated (Ten $\mu \mathrm{l}$ ) on LB agar and incubated at $37^{\circ} \mathrm{C}$ for 24 hours to ensure that the DNA plasmids are free from bacterial cells. Five $\mu$ l of DNA plasmid was added to a 
sterile Eppendorf tube contained $200 \mu$ competent cells of $E$. coli DH5 . Negative controls which consisted of competent cells without DNA for each transformation samples were plated on LB agar supplemented with certain antibiotics. The mixtures were placed on ice for 30 min and then incubated in a $42^{\circ} \mathrm{C}$ water bath for 90 seconds. The transformation samples were cooled on ice for $5 \mathrm{~min}$ and transferred to $1.5 \mathrm{ml} \mathrm{LB}$ broth in tubes and incubated with shaking at $37^{\circ} \mathrm{C}$ for 1 hour in a shaker incubator. The samples were transferred to $1.5 \mathrm{ml}$ tubes for centrifugation at 14,000 r.p.m for $1 \mathrm{~min}$. Finally, the supernatant was discarded from each sample and the pellets were spread on selective LB agar plates and incubated at $37^{\circ} \mathrm{C}$ for 24 hours $[9,10]$.

\subsubsection{Plasmid profile}

The Tris-Borate Ethelyne Diamine Tetra Acidic acid (TBE) was used to prepare agarose gel $(0.7 \%)$. This is in order to identify the bands of DNA through the gel electrophoresis as per their sizes. Melting $0.7 \mathrm{~g}$ of agarose gel powder in $100 \mathrm{ml}$ of $1 \mathrm{X}$ TBE as a buffer by heating in a microwave for 2 minutes of boiling temperature. Then after, it has been cooled down in room temperature to $55^{\circ} \mathrm{C}$ prior to pour into the gel electrophoresis tray containing the combs for DNA well and left for to be solidified. The gel and the tray filled with buffer of TBE $1 \mathrm{X}$ to sink the gel for 2-3 min, the combs removed carefully. As for molecular DNA marker, a ladder of $1 \mathrm{~kb}$ DNA (Fermentas) has been used. The wells were filled precisely with $10 \mu \mathrm{l}$ plasmid DNA extract previously mixed with $3 \mu \mathrm{l}$ of loading buffer. Voltage of 45 for 15 minutes was current to the system for 15 minutes, then after the voltage was set for a higher voltage ( 75 volts) and let to run for 90 minutes. The dye will be then noticed at the other pole of the gel. Soaking the gel in ethidium bromide $(0.5 \mu \mathrm{g} / \mathrm{ml}$ of D.W.) was necessary for half an hour in order to visualize the gel by UV-trans illuminator, figure (8).

\section{RESULTS AND DISCUSSION}

\subsection{Isolation of bacterial samples:}

Table (1) recognizes the percentage occurrence of the bacterial isolates retrieved from 75 urine specimens. This came as in following order: E. coli $(44.60 \%)$, Klebsiella pneumoniae (17.80\%), Staphylococcus spp. (12.50\%), Proteus mirabilis (12.50\%), Pseudomonas aeroginosa (7.10\%), and Enterobacter spp .(5.30\%) respectively. There is strong similarity between agents of microbes who cause UT infection whether the patient is pregnant or not. The organisms that cause UTIs during pregnancy are the same as those found in non-pregnant patients. The vast majority of infections (80\%-90\%) revealed E. coli.

\subsection{Identification of $E$. coli isolates}

The laboratory identification of $E$. coli isolates was carried out as per microscopical, cultural, morphological, and biochemical tests. Microscopic slide smear revealed short rods, motile, negatively stained with gram stain. They were motile and formed no spores. This led to a clear conclusion of the diagnostic feature of Escherichia coli, in accordance to other resources [14].
Table 1: Percentage occurrence of the bacterial isolates

\begin{tabular}{|l|c|c|}
\hline Bacterial isolates & No. & Percentages \% \\
\hline E. coli & 25 & 44.60 \\
\hline Klebsiella pneumonia & 10 & 17.80 \\
\hline Staphylococcus spp. & 7 & 12.50 \\
\hline Proteus mirabilis & 7 & 12.50 \\
\hline Pseudomonas & 4 & 7.10 \\
\hline Enterobacter spp. & 3 & 5.30 \\
\hline E.coli & 25 & 44.60 \\
\hline Klebsiella pneumonia & 10 & 17.80 \\
\hline Staphylococcus spp. & 7 & 12.50 \\
\hline Proteus mirabilis & 7 & 12.50 \\
\hline
\end{tabular}

According to their pink colony appearance on MacConkey agar as lactose fermenters, and grayish white moderately opaque with or without zone of hemolysis on blood agar, all E. coli isolates characterized by producing small, smooth, entire and convex colonies on blood agar. There was red pink lactose fermenting on MacConkey agar and producing bright metallic green sheen colonies on Eosine Methylene Blue (EMB) agar. As well as the results of biochemical tests which shown in table (2) demonstrate that all bacterial isolates understudy was positive for indole, methyle red, catalase tests, but it was negative for vogas-proskaur, citrate utilization, oxidase, no $\mathrm{H} 2 \mathrm{~S}$ production. Nevertheless, for all E. coli isolates, lactose and glucose fermentation were indicated by a yellow slant and a yellow butt A/A reaction On Kligler Iron Agar (KIA) medium [15].

Table 2: Some biochemical tests for identification of $E$. coli

\begin{tabular}{|c|c|c|c|c|c|c|c|c|c|c|c|}
\hline \multicolumn{4}{|c|}{ IMVC test } & \multicolumn{3}{|c|}{ KIA } & \multicolumn{3}{|c|}{ Hemolysin } & \multicolumn{2}{|c|}{ Others } \\
\hline$\Xi$ & $\stackrel{q}{\Sigma}$ & 今 & 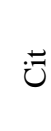 & జే & I & 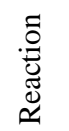 & $\uplus$ & $\infty$ & $\infty$ & 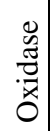 & 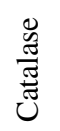 \\
\hline+ & + & - & - & + & - & $\mathrm{A} / \mathrm{A}$ & 10 & 2 & 13 & - & + \\
\hline
\end{tabular}

The production of hemolysins alpha and beta by the uropathogenic $E$. coli can cause lysis of urinary tract cells. The results revealed that out of $25 \mathrm{E}$. coli isolates, 10 isolates were œ- hemolytic, 2 isolates were B-hemolytic, and 13 isolates were gamma hemolytic representing $40 \%$, $8 \%$, and $52 \%$ respectively. Our results agree with those reported elsewhere $[16,17]$ where they found a large proportion of human extraintestinal E. coli isolates produce hemolysin representing (35-50\%) and (35-60\%) respectively, relative to normal fecal isolates (10\%). Also they mentioned that epidemiological evidence indicates a role for alpha-hemolysin in extraintestinal human infections. In general, and according to Analytic Profile Index, the synonyms number of the retrieved specimens reveals that all isolates were $E$. coli, as shown in figure (1). 


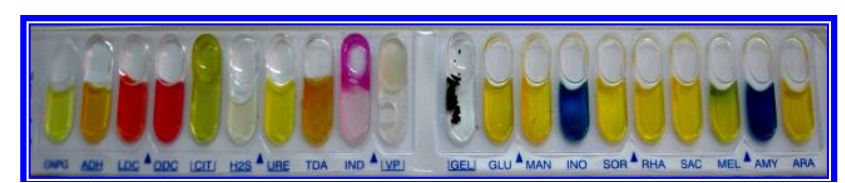

Figure 1: API 20E strip revealed E.coli (7144572)

\subsection{Antibiotic resistance pattern for the bacterial isolates}

The twenty-five $E$. coli isolated from urine samples and laboratory strain E. coli $\mathrm{DH} 5 œ$ were screened. This in order to indicate their level of resistance to ten widely used antibiotics depending on the final concentration of antibiotics (table 3). The patterns of the antibiotic resistance for the isolated bacteria are shown in (table 4). The percentages of resistant were quarantined and the isolates of the present study showed remarkable diversity in their resistance to used antibiotics used. The resistance rate of E. coli isolates ranged from 100\%, for E4, E9, E16 and E17, to 50\% For E15, E18 and E22, while the percentages of resistance for other isolates ranged between $60 \%$ and $90 \%$. Table (5) revealed that the percentage of resistant bacterial isolates to different antibiotics.

Table 3: The standard inhibition zone for different antibiotics

\begin{tabular}{|c|c|c|c|c|}
\hline 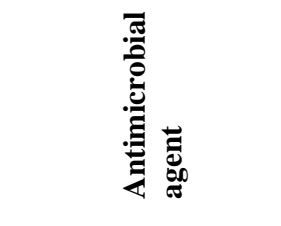 & 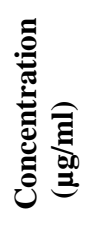 & 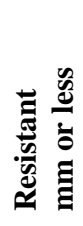 & 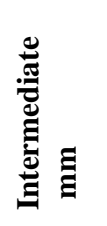 & 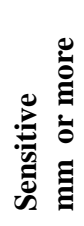 \\
\hline Amikacin (AK) & 30 & 14 & $15-16$ & 17 \\
\hline Ampicillin (AMP) & 10 & 13 & $13-15$ & 17 \\
\hline Amoxicllin & 30 & 13 & $14-17$ & 18 \\
\hline Erythromycin & 25 & 10 & $11-15$ & 16 \\
\hline Nalidixic acid (NA) & 30 & 13 & $14-18$ & 19 \\
\hline Tetracycline & 300 & 14 & $15-16$ & 17 \\
\hline Ciprofloxacin (CIP) & 5 & 15 & $16-20$ & 21 \\
\hline Penicillin & 30 & 13 & $14-19$ & 20 \\
\hline Chloramphenicol (C) & 30 & 12 & $13-17$ & 18 \\
\hline Trimethoprim & 30 & 14 & $15-22$ & 23 \\
\hline
\end{tabular}

Table 4: Antibiotic resistance pattern for E.coli isolates understudy

\begin{tabular}{|c|c|c|c|c|c|c|c|c|c|c|c|}
\hline \multirow[b]{2}{*}{ 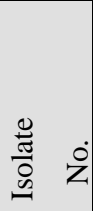 } & \multicolumn{11}{|c|}{$\begin{array}{l}\text { N. agar plates with final antibiotic concentratonis } \\
\text { in } \mu \mathrm{g} / \mathrm{ml}\end{array}$} \\
\hline & 光 & $\stackrel{\star}{<}$ & $\frac{2}{4}$ & $\Xi$ & சै & $\frac{\underline{r}}{\square}$ & $\tilde{z}$ & 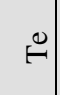 & $\Xi$ & बै & $\dot{\mathscr{0}}$ \\
\hline E1 & $S$ & $\mathrm{R}$ & $\mathrm{R}$ & $\mathrm{R}$ & $\mathrm{S}$ & $\mathrm{R}$ & $\mathrm{R}$ & $\mathrm{R}$ & $\mathrm{S}$ & $\mathrm{S}$ & $60 \%$ \\
\hline E2 & $S$ & $\mathrm{R}$ & $\mathrm{R}$ & $\mathrm{R}$ & $\mathrm{S}$ & $\mathrm{S}$ & $\mathrm{R}$ & $R$ & $\mathrm{R}$ & $\mathrm{S}$ & $60 \%$ \\
\hline E3 & $S$ & $\mathrm{R}$ & $\mathrm{R}$ & $\mathrm{R}$ & $\mathrm{R}$ & $\mathrm{R}$ & $\mathrm{S}$ & $\mathrm{S}$ & $\mathrm{S}$ & $\mathrm{R}$ & $60 \%$ \\
\hline E4 & $\mathrm{R}$ & $\mathrm{R}$ & $\mathrm{R}$ & $\mathrm{R}$ & $\mathrm{R}$ & $\mathrm{R}$ & $\mathrm{R}$ & $\mathrm{R}$ & $\mathrm{R}$ & $\mathrm{R}$ & $100 \%$ \\
\hline E5 & $S$ & $\mathrm{R}$ & $\mathrm{R}$ & $\mathrm{R}$ & $\mathrm{S}$ & $\mathrm{R}$ & $\mathrm{R}$ & $\mathrm{R}$ & $\mathrm{S}$ & $\mathrm{R}$ & $70 \%$ \\
\hline E6 & $S$ & $\mathrm{R}$ & $S$ & $\mathrm{R}$ & $\mathrm{R}$ & $\mathrm{R}$ & $\mathrm{R}$ & $\mathrm{R}$ & $\mathrm{S}$ & $\mathrm{R}$ & $70 \%$ \\
\hline E7 & $\mathrm{R}$ & $\mathrm{R}$ & $\mathrm{R}$ & $\mathrm{R}$ & $\mathrm{R}$ & $\mathrm{R}$ & $\mathrm{R}$ & $\mathrm{S}$ & $\mathrm{R}$ & $\mathrm{S}$ & $80 \%$ \\
\hline E8 & $S$ & $\mathrm{R}$ & $\mathrm{R}$ & $\mathrm{R}$ & $\mathrm{R}$ & $\mathrm{R}$ & $\mathrm{R}$ & $\mathrm{R}$ & $\mathrm{R}$ & $\mathrm{R}$ & $90 \%$ \\
\hline E9 & $\mathrm{R}$ & $\mathrm{R}$ & $\mathrm{R}$ & $\mathrm{R}$ & $\mathrm{R}$ & $\mathrm{R}$ & $\mathrm{R}$ & $\mathrm{R}$ & $\mathrm{R}$ & $\mathrm{R}$ & $100 \%$ \\
\hline E10 & $S$ & $\mathrm{R}$ & $\mathrm{S}$ & $\mathrm{R}$ & $\mathrm{S}$ & $\mathrm{R}$ & $\mathrm{R}$ & $\mathrm{R}$ & $\mathrm{S}$ & $\mathrm{R}$ & $60 \%$ \\
\hline E11 & $\mathrm{R}$ & $S$ & $\mathrm{R}$ & $\mathrm{R}$ & $\mathrm{S}$ & $\mathrm{R}$ & $S$ & $\mathrm{R}$ & $S$ & $\mathrm{R}$ & $60 \%$ \\
\hline E12 & $S$ & $\mathrm{R}$ & $\mathrm{R}$ & $S$ & $S$ & $\mathrm{R}$ & $\mathrm{R}$ & $\mathrm{R}$ & $\mathrm{R}$ & $\mathrm{S}$ & $60 \%$ \\
\hline E13 & $\bar{S}$ & $\bar{R}$ & $\mathrm{~S}$ & $\mathrm{R}$ & $\mathrm{S}$ & $\mathrm{R}$ & $\mathrm{R}$ & $\mathrm{R}$ & $\mathrm{R}$ & $\mathrm{S}$ & $60 \%$ \\
\hline E14 & $S$ & $\mathrm{R}$ & $\mathrm{R}$ & $\mathrm{R}$ & $\mathrm{R}$ & $\mathrm{R}$ & $\mathrm{R}$ & $\mathrm{R}$ & $\mathrm{R}$ & $\mathrm{R}$ & $90 \%$ \\
\hline E15 & $S$ & $\mathrm{R}$ & $\mathrm{S}$ & $S$ & $\mathrm{~S}$ & $\mathrm{R}$ & $\mathrm{R}$ & $\mathrm{R}$ & $\mathrm{S}$ & $\mathrm{R}$ & $50 \%$ \\
\hline E16 & $\mathrm{R}$ & $\mathrm{R}$ & $\mathrm{R}$ & $\mathrm{R}$ & $\mathrm{R}$ & $\mathrm{R}$ & $\mathrm{R}$ & $\mathrm{R}$ & $\mathrm{R}$ & $\mathrm{R}$ & $100 \%$ \\
\hline E17 & $\mathrm{R}$ & $\mathrm{R}$ & $\mathrm{R}$ & $\mathrm{R}$ & $\mathrm{R}$ & $\mathrm{R}$ & $\mathrm{R}$ & $\mathrm{R}$ & $\mathrm{R}$ & $\mathrm{R}$ & $100 \%$ \\
\hline E18 & $\mathrm{R}$ & $\mathrm{R}$ & $\mathrm{R}$ & $\mathrm{R}$ & $\mathrm{S}$ & $\mathrm{R}$ & $S$ & $\mathrm{~S}$ & $\mathrm{~S}$ & $\mathrm{~S}$ & $50 \%$ \\
\hline E19 & $S$ & $\mathrm{R}$ & $\mathrm{R}$ & $\mathrm{R}$ & $\mathrm{S}$ & $\mathrm{R}$ & $\mathrm{R}$ & $\mathrm{R}$ & $S$ & $\mathrm{R}$ & $70 \%$ \\
\hline E20 & $\mathrm{R}$ & $\mathrm{R}$ & $\mathrm{R}$ & $\mathrm{R}$ & $\mathrm{R}$ & $\mathrm{R}$ & $\mathrm{R}$ & $\mathrm{R}$ & $\mathrm{S}$ & $\mathrm{R}$ & $90 \%$ \\
\hline E21 & $S$ & $\mathrm{R}$ & $\mathrm{R}$ & $\mathrm{R}$ & $\mathrm{S}$ & $\mathrm{R}$ & $\mathrm{R}$ & $\mathrm{R}$ & $\mathrm{S}$ & $\mathrm{R}$ & $70 \%$ \\
\hline E22 & $S$ & $\mathrm{R}$ & $\mathrm{S}$ & $\mathrm{S}$ & $\mathrm{S}$ & $\mathrm{R}$ & $\mathrm{R}$ & $\mathrm{R}$ & $\mathrm{R}$ & $\mathrm{S}$ & $50 \%$ \\
\hline E23 & $S$ & $\mathrm{R}$ & $\mathrm{R}$ & $\mathrm{R}$ & $\mathrm{S}$ & $\mathrm{S}$ & $\mathrm{R}$ & $\mathrm{R}$ & $\mathrm{R}$ & $\mathrm{S}$ & $60 \%$ \\
\hline E24 & $S$ & $\mathrm{R}$ & $\mathrm{R}$ & $\mathrm{R}$ & $\mathrm{S}$ & $\mathrm{R}$ & $\mathrm{R}$ & $\mathrm{R}$ & $\mathrm{R}$ & $\mathrm{R}$ & $80 \%$ \\
\hline E25 & $S$ & $\mathrm{R}$ & $\mathrm{R}$ & $\mathrm{R}$ & $\mathrm{S}$ & $\mathrm{R}$ & $\mathrm{R}$ & $\mathrm{R}$ & $\mathrm{S}$ & $\mathrm{S}$ & $60 \%$ \\
\hline
\end{tabular}

Table (5) elucidated that the highest percentage of resistance was $96 \%$ to Ap, while the lowest percentage was $32 \%$ for Ak. The results also clarified that E. coli isolates showed different resistance to Ery, Tet, $\mathrm{Cm}$, Nal, Ax, Pen, Tm and Cip and the resistant rate were $92 \%$, $88 \%, 88 \% .88 \%, 80 \%, 64 \%, 52 \%$, and $40 \%$ respectively. Multiple resistances to two or more antibiotics was common. The results revealed that resistance to ampicilin and erythromycin was $96 \%$ and $92 \%$ respectively, similar results were reported [18, 19, and 20] they found that resistance of isolates of $E$. coli retrieved from urinary tract infections to ampicilin were $90 \%, 95 \%$ and $92 \%$ respectively. Studies elsewhere $[21,22]$ stated that no $E$. coli isolates from UTIs were sensitive to ampicillin. 
Table (5): Percentages of resistant bacterial isolates to different antibiotics

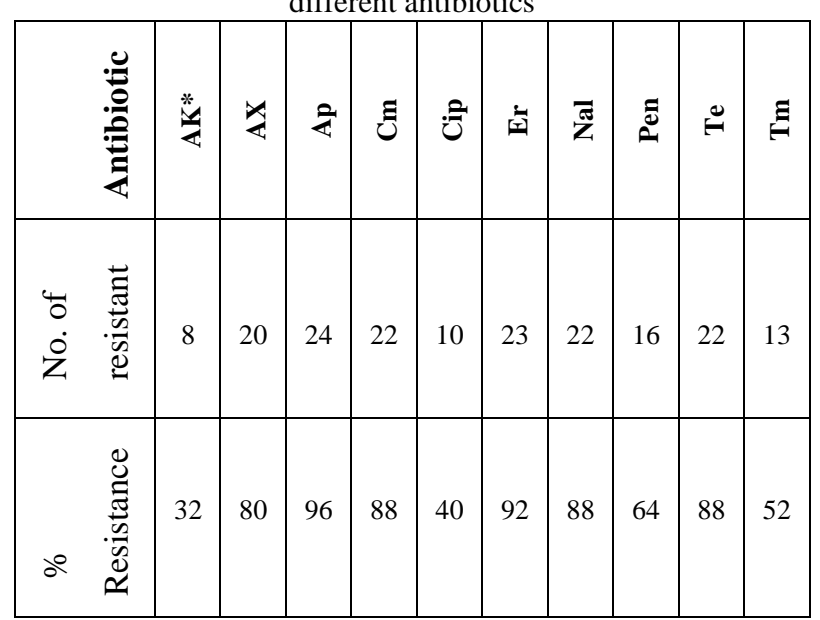

In the present study high resistance percentages (88\%) was reported to chloramphenicol, tetracycline, naldixic acid. However, [23] found the resistant percentages of $E$. coli to naldixic acid were (86\%), while [22] stated that a resistance percentage of $E$. coli to nalidixic acid was $(20 \%)$. The resistance to quinolones as naldixic acid in gram- negative bacteria such as $E$. coli is mainly recalled to a mutation in their chromosome which modifies the targeted enzyme of the bacterium (DNA gyrase) and topoisomerase IV, or enhnce the efflux pump system that drain the drugs out of the cytoplasm.

This study showed that the resistant to tetracycline was $(88 \%)$, similar results reported by [24], he also stated that resistant to tetracycline was $(88 \%)$, resistant with a percentage of $(79 \%)$ obtained in other study [22]. These results correlated with the study done by [25], who revealed that $(73.3 \%)$ of $E$. coli isolated from UTIs were resistant to tetracycline. Chloramphenicol resistant percentages that recorded in this study was (88\%), while others reported $(70 \%)$ of $E$. coli susceptible to chloramphenicol [24]. Moreover research showed that $E$. coli isolated from UTIs were resistant to chloramphenicol at a percentage of $(60 \%)$ [18], others reported that $(39 \%)$ of E. coli isolates were resistant to chloramphenicol [26]. This diversity and multiple antibiotic resistance of E. coli are linked to genes located on their conjugant plasmid. Nevertheless, processes of conjugation, transformation or transduction can aid the transfer of these genes to recipient $E$. coli. The resistance genes can also occur on the circular chromosome of the bacterium and can dive to the plasmid by a process of transposition. Transposon may bear genes of multidrug resistance and both grampositive and gram negative bacteria can perform such a process of transposition of genes [27].

\subsection{Determination of the genetic site determination of} antibiotic resistance in $E$. coli

The isolates of the present study were gone through a transformation experiment in order to uncover the locus of the antibiotic resistant gene in the $E$. coli isolates. Transformation was obtained by using DH5œ E. coli strain, as a recipient cell. It has the capability to resolve clean and purified E. coli plasmid DNA content from bacterial isolates. Four isolates were chosen from the bacterial isolates that show resistance to most antibiotics understudy. The antibiotic resistance pattern of those isolates and the laboratory DH5œ strains are shown in (table 6).

Table 6: Antibiotic resistance patterns of chosen acterial isolates used for transformation process

\begin{tabular}{|c|c|c|c|c|c|c|c|c|c|c|}
\hline \multirow{2}{*}{ 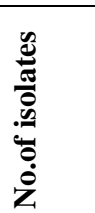 } & \multicolumn{10}{|c|}{$\begin{array}{l}\mathrm{N} \text {-agar with final antibiotic concentration in } \\
\mu \mathrm{g} / \mathrm{ml}\end{array}$} \\
\hline & $\stackrel{*}{\stackrel{*}{Z}}$ & 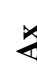 & $\frac{2}{4}$ & $\exists$ & $\stackrel{\bar{v}}{ }$ & 도 & $\bar{z}$ & $\underset{0}{0}$ & $\stackrel{\vec{\omega}}{=}$ & 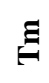 \\
\hline E4 & S & $\mathrm{R}$ & $\mathrm{R}$ & $\mathrm{R}$ & $\bar{R}$ & $\mathrm{R}$ & $\mathrm{R}$ & $\mathrm{R}$ & $\mathrm{R}$ & $\mathrm{R}$ \\
\hline E16 & $\mathrm{R}$ & $\mathrm{R}$ & $\mathrm{R}$ & $\mathrm{R}$ & $\bar{R}$ & $\mathrm{R}$ & $\mathrm{R}$ & $\mathrm{R}$ & $\mathrm{R}$ & $\mathrm{R}$ \\
\hline DH5œ & $\mathrm{S}$ & $S$ & $\mathrm{~S}$ & $\mathrm{R}$ & $\mathrm{S}$ & $\mathrm{S}$ & $\mathrm{R}$ & $\mathrm{R}$ & $\mathrm{S}$ & $\mathrm{S}$ \\
\hline
\end{tabular}

The L.B medium was used to subculture 10 colonies of DH5- $\alpha$ transformants. This process is crucial as it guarantees the phenotypic stability of resistance in the transformed colonies. In addition, it ensures proper and regular segregation of plasmids after purification. Finally, the colonies were tested for antibiotic resistance through Kirby-Bauer method. Results were as in table (7).

Table 7: Antibiotic resistance pattern after transformation of E.coli DH5- $\alpha$ With purified plasmid from E.coli isolates

\begin{tabular}{|c|c|c|c|c|c|c|c|c|c|c|}
\hline \multirow{2}{*}{ 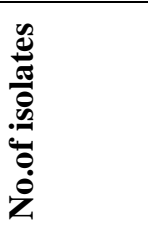 } & \multicolumn{10}{|c|}{$\begin{array}{l}\text { N-agar with a final antibiotic } \\
\text { concentration in } \mu \mathrm{g} / \mathrm{ml}\end{array}$} \\
\hline & $\stackrel{*}{*}$ & $\stackrel{x}{4}$ & $\frac{2}{4}$ & $\Xi$ & ¿ & 空 & $\overline{\mathbf{Z}}$ & 胥 & a & $\boldsymbol{\Xi}$ \\
\hline E4 & $\mathrm{S}$ & $\mathrm{R}$ & $\mathrm{R}$ & $\mathrm{R}$ & $\mathrm{R}$ & $\mathrm{R}$ & $\mathrm{R}$ & $\mathrm{R}$ & $\mathrm{R}$ & $\mathrm{R}$ \\
\hline $\begin{array}{l}\text { DH5œ+ } \\
\text { plasmid }\end{array}$ & $S$ & $\mathrm{~S}$ & $\mathrm{~S}$ & $\mathrm{R}$ & $\mathrm{S}$ & $\mathrm{R}$ & $\mathrm{R}$ & $\mathrm{R}$ & $\mathrm{R}$ & $\mathrm{R}$ \\
\hline E16 & $\mathrm{R}$ & $\mathrm{R}$ & $\mathrm{R}$ & $\mathrm{R}$ & $\mathrm{R}$ & $\mathrm{R}$ & $\mathrm{R}$ & $\mathrm{R}$ & $\mathrm{R}$ & $\mathrm{R}$ \\
\hline $\begin{array}{l}\text { DH5œ+ } \\
\text { plasmid }\end{array}$ & $\mathrm{R}$ & $\mathrm{S}$ & $\mathrm{S}$ & $\mathrm{R}$ & $\mathrm{S}$ & $\mathrm{R}$ & $\mathrm{R}$ & $\mathrm{R}$ & $\mathrm{R}$ & $\mathrm{R}$ \\
\hline
\end{tabular}

From the table, it's obvious that the transformation process performed successfully for each of E4 and E16. This is indicated by resistance to Er, Tm, and Te, for E4 transformant and to Ak, Er, and Tm for E16. The profile of the plasmids in transformed E. coli DH5- $\alpha$ strain with purified plasmid from E4, and E16 isolates (Figure 2) revealed that successful transformation is retrieved only in a single band (>10000 bp) that can show resistance of DH5- $\alpha$ to above antibiotics. This may be related to the fact that the responsible genes of a known resistance could be located on a large plasmid or the chromosomal DNA. This results in difficulty of uptake by the DH5œ receiver, or has a transposon property. Thus, we can conclude that all genes responsible for conferring resistance to antibiotics used (Ak, Er, Te, and Tm) are located on plasmid DNA. 
Figure 2: Plasmid profile of transformant colonies

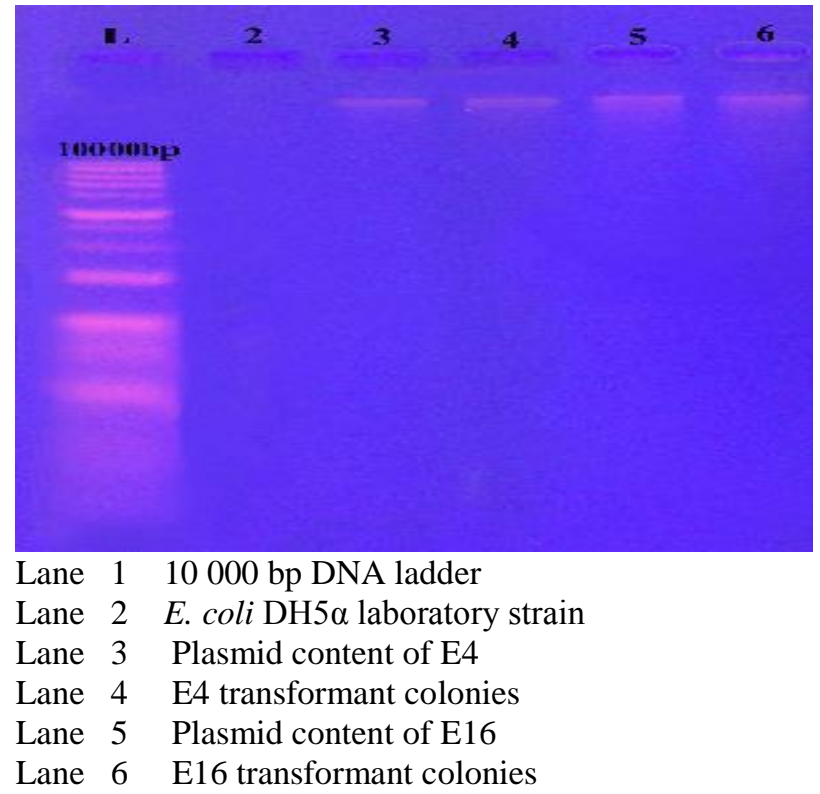

The size of the plasmids of bacterial isolates of which transformation test with DH5- $\alpha$ transformant performed can be the reason behind the diversity of antibiotics resistance. The size also determines the fluency and easiness off the entrance to the cells during transformation [28]. A study suggested that transferring $f$ the genes horizontally may be a factor behind capability of clinical isolates to resist antibiotics [29]. Suggesting that consuming an antibiotic is not the only reason of the increased frequency of resistance to a particular antibiotic as previously stated by relevant works [30]. Research of others mentioned that after transformation with plasmid DNA in uropathogenic E. coli isolated from pregnant women, transformant colonies become resistance for gentamycin, trimethoprime, amikacin and tetracycline [31].

On the other hand, the ability of purified DH5œ transformant colonies to produce hemolysin were tested on blood agar using streaked plate method and the results demonstrate the inability of the transformant colonies to produce alpha or beta hemolysins [32].

\section{CONCLUSION}

From these results it is clear that the genes responsible for encoding hemolysin enzymes were located on chromosome and thus not transferred to the host competent cells during transformation.Alpha-hemolysin is a virulence-associated factor that has been found to be chromosomally encoded in most human urinary tract isolates and it has also been assumed that this determinant can be related to the pathogenesis of extraintestinal E. coli human infections.

\section{REFERENCE}

[1] C. W. Tan and M. P. Chlebicki, "Urinary tract infections in adults,"Singapore Med J, vol. 57, pp. 485-90, Sep 2016.

[2] A. Al-Faisal, Genetic engineering, Dar Al-Shrooq for publishing, Amman, Jordan, 1999.

[3] K.C. Carroll, S.A. Morse, T. Mietzner, and S. Miller, Jawetz, Melnick, and Adelberg's Medical Microbiology, 27th Ed. McGraw-Hill Education, USA, 2016.
[4] R. M. Atlas, A. E. Broun and L. C. Parks, Laboratory manual of experimental microbiology, Mosby, St. Louis Baltimore, U.S.A. 1995.

[5] P. Hawky and D. Lewis, Medical bacteriology, 2nd edition, Oxford University Press. Inc, UK, 2004.

[6] H. C. Brinboim and J. Doly, "A rapid alkaline extraction procedure for screening recombination plasmid DNA,", Nucleic acid research. Vol. 7, pp. 1513-1524, 1979

[7] J. Sambrook and D. W. Russell, Molecular cloning: a laboratory manual, 3rd edition, Cold spring, Herbour Lab., New York. USA, 2001

[8] M. Mandel and A. Higa, "Calcium-dependent bacteriophage DNA infection. 1970," Biotechnology, vol. 24, pp. 198-201, 1992.

[9] E. M. Lederberg and S. N. Cohen, "Transformation of Salmonella typhimurium by plasmid deoxyribonucleic acid," J Bacteriol, vol. 119, pp. 1072-4, Sep 1974

[10] W. P. M. Hoekstra, H. E. N. Bergmans, and E. M. Zuidweg, "Transformation in Escherichia coli: studies on the nature of donor DNA after uptake and integration," Genetical Research, vol. 35, no. 3, pp. 279-289, 1980.

[11] C. Turpin, B. Minkah, K. Danso, and E. Frimpong, "Asymptomatic bacteriuria in pregnant women attending antenatal clinic at komfo anokye teaching hospital, kumasi, ghana," Ghana Med J, vol. 41, pp. 26-9, Mar 2007.

[12] J. R. Johnson, "Virulence factors in Escherichia coli urinary tract infection," Clin Microbiol Rev, vol. 4, pp. 80-128, Jan 1991.

[13] J. E. Blanco, M. Blanco, A. Mora, and J. Blanco, "Prevalence of bacterial resistance to quinolones and other antimicrobials among avian Escherichia coli strains isolated from septicemic and healthy chickens in Spain," J Clin Microbiol, vol. 35, pp. 2184-5, Aug 1997.

[14] S. Sharma, G. K. Bhat, and S. Shenoy, "Virulence factors and drug resistance in Escherichia coli isolated from extraintestinal infections," Indian J Med Microbiol, vol. 25, pp. 369-73, Oct 2007.

[15] G. Wistreich, A. Kleemm and M. D. Lechtman, Laboratory exercises in Microbiology, $4^{\text {th }}$ ed., Glencoe publishing Co. Inc, New York, 1980.

[16] A. E. Barber, B. A. Fleming, and M. A. Mulvey, "Similarly Lethal Strains of Extraintestinal Pathogenic Escherichia coli Trigger Markedly Diverse Host Responses in a Zebrafish Model of Sepsis," mSphere, vol. 1, Mar-Apr 2016.

[17] M. D. Engstrom and H. L. Mobley, "Regulation of Expression of Uropathogenic Escherichia coli Nonfimbrial Adhesin TosA by PapB Homolog TosR in Conjunction with H-NS and Lrp," Infect Immun, vol. 84, pp. 811-21, Jan 112016.

[18] M. Abd-Alsattar, Partial purification of type-1pili extracted from E. coli and its role in infection, .Ph.D.Thesis, College of Science, University of Baghdad, 2004.

[19] U. Asad and S. Zaman, "Multiple drug resistance pattern in urinary tract infection patients in Aligarh," Biochemical research, vol. 17, pp.179-181, 2006.

[20] M. H. Shirazi, N. Sadeghhifard, R. Ranjbar, E. Daneshyar and A Ghasemi, "Incidence of asymptomatic bacteriuria during pregnancy, " Pak. J. Biol. Sci. , vol. 9, pp. 151-154, 2006.

[21] A. M. G. Al-Fahdawi, Influence of blood groups on the availability of receptors of uroepithelial cells for attachment of uropathogenic bacteria causing urinary tract infections, M.Sc thesis, College of Medicine, University of Baghdad, Baghdad, Iraq, 2001

[22] A. N. H. Al-Alosi, Molecular study on some virulence factors produced by Gram-negative bacteria, M.Sc. thesis, Genetic Enginnering and biotechnology Institute for post graduate studies, University of Baghdad, Baghdad, Iraq, 2004.

[23] A. N. Ghosh, D. R. Bhatta, M. T. Ansari, H. K. Tiwari, J. P. Mathuria, A. Gaur, et al., "Application of WHONET in the Antimicrobial Resistance Surveillance of Uropathogens: A First User Experience from Nepal," J Clin Diagn Res, vol. 7, pp. 8458, May 2013.

[24] M. M. Al-Shaikhli, Virulence factors of E.coli in women with asymptomatic bacteriuria, M.Sc thesis, College of Medicine, Baghdad University, Baghdad. Iraq, 2004.

[25] A. Sharma and P. Grover, "Application of whonet for the surveiallance of antimicrobial resistance, " Indian. J. Med. Microbiol., vol. 22, pp.115-118, 2004.

[26] S. Babypadmini and B. Appalaraju, "Extended spectrum lactamases in urinary isolates of Escherichia coli and Klebsiella pneumoniae - prevalence and susceptibility pattern in a tertiary 
care hospital," Indian J Med Microbiol, vol. 22, pp. 172-4, JulSep 2004.

[27] A. Moghadas and G. Irajian, "Asymptomatic urinary tract infection in women," Iranian Journal of Pathology, vol. 4, pp.105108, Jul 2009.

[28] N. Woodford and A. Johnson, Molecular Bacteriology, Protocols and clinical applications, Humana press Inc, 1998.

[29] J. R. Brown, D. Gentry, J. A. Becker, K. Ingraham, D. J. Holmes, and M. J. Stanhope, "Horizontal transfer of drug-resistant aminoacyl-transfer-RNA synthetases of anthrax and Grampositive pathogens," EMBO Rep, vol. 4, pp. 692-8, Jul 2003.

[30] P. Nwanze, L. Nwaru, S. Oranusi, U. Dimkpa, M. Okwu, B. Babatunde, T. Anake, W. Jatto and C. Asagwara, "Urinary tract infection in Okada village: Prevalence and antimicrobial susceptibility pattern," Scientific Research and Essay, vol. 2, pp. 112-116. 2007

[31] Z. A. Nanakaly, Characterization of plasmid DNA content and antimicrobial effect of bile salt on E.coli isolated from urinary tract infection of pregnant women, Thesis of Higher Diploma, College of Education, Salahaddin University, Erbil, Iraq, 2010.

[32] P. Siskova, L. Cernohorska, M. Mahelova, K. Turkova, and V. Woznicova, "Phenotypes of Escherichia coli isolated from urine: Differences between extended-spectrum beta-lactamase producers and sensitive strains," J Microbiol Immunol Infect, vol. 48, pp. 329-34, Jun 2015. 